\title{
The Importance and Necessity of Paying Attention to Law and Legalism in Social Areas from the Perspective of the Holy Quran
}

\author{
Reza Alami (Corresponding author) \\ Faculty of Management Lincoln University College Malaysia, Branch Iran \\ E-mail: rezaalami49@yahoo.com
}

Farzad Emamian

Jurisprudence and Principles of Islamic Law graduate student Payam Noor University

Sari, Mazandaran, Iran

Seyed Nima Karimi

Graduate Student of International law, Islamic Azad University

Qaemshahr, Mazandaran, Iran

Seyed Sadegh Mousavi Takami

Jurisprudence and Principles of Islamic Law graduate student Payam Noor University of Sari, Mazandaran, Iran

Mahdi Rezaei

Jurisprudence and Principles of Islamic Law graduate student Payam Noor University of Sari, Mazandaran, Iran

Received: November 28, 2015 Accepted: December 23, 2015 Published: April 21, 2016

doi:10.5296/ijch.v2i2.8639 URL: http://dx.doi.org/10.5296/ijch.v2i2.8639 


\section{Abstract}

Social life is an inevitable necessity for human beings and order, security and justice is required for social life. In this regard, everything that can be effective social life of for human beings should be seriously considered. Law is among these phenomena that people can benefit from social life in its light in addition to benefiting from their natural rights. Therefore, it can be said that the strength and cohesion of any society is paying attention to the law and obeying it. Obviously, this religion in order to convey its purpose should have a plan for them. Therefore, God, as the drafter of this religion sent the Quran to people which is full of solutions and values and a better life for them. In Islam and Quran, the condition of salvation and happiness of a society depends on adherence to God's laws and regulations in all facets and social arenas. The results of this study show that in the shadow of respecting law and order the possibility of planning, implementing and guiding in human society is done. A society can only be lawful by fulfilling God's commandments in Quran.

Keywords: Religion, Quran, Law, Society, Islam

\section{Introduction}

Quran is an action plan and a strategy which covers all the principles and provisions of individual life, as well as the type of interaction of Creator of the universe with man, all the existing phenomena and the type of his relationships with family, neighbors, society, Islamic nation and even non-Islamic people and their creeds. Quran has fixed a set of values as the basis of its doctrine and has invited or sometimes has mandated human beings that adhere to these human values to reach peace and to cause peace and well-being of their family and society (Majlesi, 1984). Past experience of history is clear evidence that human laws have never created a regulated and flawless society. With their special support and in every time and place, God rules in Quran are able to create a healthy and virtuous society. This society is within the limits of divine laws and it does not go beyond. understanding of those rules, interpreting them based on human needs at all times and finally realizing them is our task in the beginning (Meshkini, 1985). If these two tasks are done, there will be a society that in addition to the benefits of civil society will have special privileges of The Muslim community. This paper seeks to explain the position of the law and legalism from the perspective of the Qur'an.

\section{Statement of the Problem}

From the beginning of human life, some people have attempted to impose the rule of law in society in order to create law and authorizing it in the society. But in the course of history up to now, experience has shown that human laws have failed to create a law-oriented society and enforcement of these laws haven't thoroughly tried to protect the law and practicing it. Only divine law can create a healthy and law-oriented society; as the prophets and their righteous successors were those who acted properly in law and protected it. By legalism it is meant to protect and implement the law fairly and respecting the rights of all people in society (Mohammadi Reyshahri, 2002). A law-abiding and law-oriented society is the one in which rules are fully respected and all individuals are equal before the law and its leaders are the most submissive people in society. The necessity of the law and legalism has always been 
considered from the beginning of human life. Throughout history, some people have attempted to legislate and enforce it in order to establish order in society. But human experience has shown that the long history, rules, as necessary, haven't protected laws and have failed in practicing it (Jaafari Langroodi, 2001). Divine rules are the only law which can create a healthy society and law-oriented society. The only people who have the rule of law to their agenda and appropriately followed and protected the divine law are prophets and their rightful successors. Quran, without doubt, is the most complete book, and Islam is the perfect religion, there is a great emphasis on following the law in the social arena of life in different societies and at different periods. Quran despite being a comprehensive book and being a practical means for researchers in different areas is not used optimally.

One of the issues that can be addressed in the Qur'an is laws and regulations and respecting the rights of the society and social relations (Zahedi, 2002). Obviously, Islam guarantees human happiness in all aspects of life and it determines policies and practices of individual of their individual and social life. In Islam and Quran, the condition for Prosperity and salvation of a society depend on adherence to God's laws and regulations in all aspects and social arenas. So today`s society needs to follow the Quran and its teachings about legalism to have a society full of justice and equality and to provide grounds for the Savior of mankind. Studies show that despite the observations and research that has been done in the Quran and the teachings of the Quran, Unfortunately, some of the important issues are neglected or ignored Researchers, one of these issues is the discussion of Legalism in Quran.

If the laws and regulations on social relations in modern society are rooted in and derived from the Quran, it can be very helpful in spreading justice, fairness and equality among people and government and reducing social deviations in different areas society. And if it is ignored, it causes Distrust, increased social deviations and inequality in society, and it provides the ground for fall and vulgarity.

\section{The Definition of Law}

The law was originally derived from hotspot, and it was first enacted for tools and devices which were used to regulate lines. But later, its concept was expanded and used for all the rules and laws needed and necessary for society. As far as in the current situation, the purpose of it is just a set of instructions that are needed to run a society. In another interpretation, law is a Syria word meaning ruler; it is a rule of law which has been passed by legislative bodies. It does not only contain regulations and approval letters, in the past law was spread by tablets and scrolls that were installed in public places like inscriptions of Hammurabi (Haghpanah, 1988). In legal terms, this word is used in different situations like using it for the law to set rules in a land, or using it for the constitution, or for expressing existing laws which in this case will not include administrative guidelines and regulations. And occasionally, the set of operating practices of the government and the regulations governing it are considered as legal moves in the direction of improving the operational structure of the government. Accordingly, even non-formal moves are legalized and are justified in the light of law and do not require statutory and authoritative rules (Haghpanah, 1988). Rule has a specific meaning in different sciences; like the rules of nature, mathematical rules, philosophical rules and physical rules 
that each is specially defined. In terms of fundamental rights, law includes cases which determine how human behave in social life; this means that people in personal and social life should not do so and so. The rule of law means Maintaining and enforcing laws fairly and respecting the rights of all individuals in society. Therefore, a law-abiding and law-oriented society is the one in which rules are fully respected and that all people are equal before the law (Haghpanah, 1988).

\section{The Role of Law}

The main function of law is regulating the behavior of members of a society which naturally have a conflict. Law is like a Social engineering ruler which marks structures of society at different levels. Law is society's wisdom. Wisdom controls ambitions and violence in the human soul, law also controls seeking too much power and wealth (which lead to conflict and violence). The role of correct law which is based on humanitarian principles is determining the limits, eliminating disputes, repelling the aggression, arbitration among people, demonstrating the excellence and perfection, establishing order and justice and providing contexts for human evolution (Shihab al-Dini, 1983). Sensitivity and importance of law becomes more visible by complexities of societies. Law has an evolutionary trend along with Social development. Brief and incomplete law creates incomplete order and more complete societies demand more complete law in order to play its proper role, of course, in addition to establishing and maintaining discipline, a higher purpose for the law is considered which is spiritual evolution. However, we can say that the law is a tool that: 1. organizes personal and social life of people. 2. makes social reforms possible. 3. specifies the evolutional direction of human movement and social developments (Tabatabai, 1989).

Reaching this goal and playing such a role is not possible by ordinary and humanitarian laws and is only accessible by divine law. Human life is a social life. Social living requires interference and collision among the interests of society`s members; because there are people who want to enjoy the fruits of social cooperation, use natural resources indefinitely or want to deal with others as they desire which is not accepted by others. So some conflicts occur inevitably in the society. We need boundaries and rules to eliminate or reduce these interferences to specify the limits of exploitation of human beings (Roche, 2005). Because if there are no boundaries for the exploitation of human or people do not respect them, the purpose of social life, which is more exploitation of the natural resources for the material and spiritual development of human beings, will not be fulfilled. Consequently, the law is necessary for society in order for its members' benefit from material and spiritual advantages by respecting it (Mesbah, 1996).

\section{The Role and Position of Law}

Law Links the various layers of society, hence, it has an important role and position in society. The main function of law is to regulate the behavior of members of a society who naturally have conflicts. The role of correct law which is based on humanitarian principles is determining the limits, eliminating disputes, repelling the aggression, arbitration among people, demonstrating the excellence and perfection, establishing order and justice and providing contexts for human evolution (Roche, 2005). So in addition to regulating people's 
personal and social life and enabling social reforms, one of the key aims of the law is to specify the direction for the development of human and social development path. It is not possible with ordinary laws and can only be possible by Divine law which its complete example is life-giving laws of God which is sent to human beings by the Prophet of Islam. The Prophet who had the role of notifying and enforcing Islam's life-giving rules has considered a prominent status for it. He considered enforcing criminal law of Islam on violators of more important than forty nights of rain (Mohammadi Reyshahri, 2002).

\section{The Rule of Law as A Matter of Quran-Valued Issue}

Quran has set a fixed set of values as the basis of its doctrine and invited and sometimes required people to adhere to human values so they can reach peace and also cause their families and society to do so (Khorramshahi, 2008). Some of these values are:

\subsection{Returning to the Pure Human Nature}

Quran considers nature-based invitation as the basis of its teaching and its teaching is accompanied by human nature. It believes that all human beings have a pure nature and the ability to accept and recognize the truth. Thus requires people to return to their pure nature and relying on it, choose a path and belief which is closer to their nature and is consistent with it and finally become a source of happiness and prosperity in this world and hereafter. Quran considers human's wisdom as its basis for recognizing right and wrong and demands them to follow the wisdom and knowledge and choose the right path for a better life. That is why God in Quran gives examples in many verses which can only be understood by wise people (Khorramshahi, 2008).

\subsection{Moderation and Prudence in Life}

Quran asks man to pay attention to both spiritual and worldly life simultaneously. God asks people to think of this world as hereafter farm and benefit from its countless blessings without thinking of it as their ultimate goal and with foresight and vision make effort for their world as if they will remain there forever and they also work for the Hereafter as if life ends tomorrow and in this case, they will achieve happiness both in this world and the Hereafter.

\subsection{Responsibility and Honesty in Words and Deeds}

Honesty and trustworthiness are great moral values which are recalled in every religion and their implementation is emphasized. Imagine a society whose members do not act together except for true speech and action, do not break their promises, do tasks laid upon them in the best way and without any negligence or delay, Quran invites and commands Muslims to be honest and responsible in many verses.

\section{The Rule of Law from the Perspective of Quran}

Man is a social creature and Quran is a book full of recommendations and social provisions, inevitably religion must be social and life-promoting. There are people who think of human as creatures with social nature i.e. they are forced and obliged to be social and there are some people who think of religion as being devoid of social dimension and without a system. The 
fact of Islam having a system is different from its being social or not, so Islam can be known as a social religion of and the Quran is a book that guides society toward worldly - and otherworldly salvation and yet deny the existence of their social system (Payandah, 2001). When Quranic verses and Islamic traditions have passages that are used to explicitly require people together and complementing each other, there is no room for doubt that this religion and its book are the most social phenomena of the universe (Zahedi, 2002). Since human material and spiritual needs are diverse, they are forced to meet these requirements and needs by getting help from experiences, facilities and aid of others so that the foundation, development and provision of social civilization is impossible without imagining social life. Civil and social man who is forced to live in the community should put aside many of their desires or moderate them and if they want to do so they will need law and regulations; because society and social life not only can be created without rule of law and monitoring its implementation, but also it will not continue in case of being created. If the corruption is spread among the population, the balance of the universe is ruined and causes the deterioration and impaired blessing of life. As a result, corruption is in land and sea which reflects the action of people and is a product of their behavior. These are all the result of not following the rules and its failure and creating distortions in society (Tabatabai, 1989). Thus, from the very beginning, when man chose social life inevitably, realized this obvious fact that for better living and avoidance of conflict and preventing the collapse of the foundations of social life, they need standards and they need to achieve individual and social salvation by "legitimacy of society`s affairs" and " following of law by people". The result is that the existence of law is necessary for social life and is a means to prevent man's degeneration. However, law is necessary to bring back man to the right path after declining in their social lives However, laws and regulations is essential to human social life (Cohen, 2000).

\section{The Importance of Rule of Law from Different Perspectives}

To understand the importance of rule of law it is sufficient to say that law is the basis of order, stability of a country. And the guarantee of a society's life depends on the law, it is Frequently mentioned in the Quran, Sociologists also stated that which will be dealt with.

\subsection{Guarantee the Life and Survival of Society}

Among many factors that sociologists have identified as important factors in the survival of the social system, "continuity of cultural heritage" can be cited as the most important factor. On the other hand, the only way to sustain cultural heritage that ensures the survival of a social system, is "Socialization" of that human system and "socialization" can mean "accepting the law", Because socialization is a process during which members of the community become disciplined, responsible, conscientious and law- oriented people. If the members of society are indifferent about institutions and social norms which are considered as Sustainable answers for important and sustainable issues of social system and do not show discipline and commitment toward Legal rules and informal norms and customs of society and principles of functioning of its institutions, foundation of the social system will be perilously threaded and its operation and performance is seriously impaired. Therefore, what ensures the survival of the community and its function is the rule of law in society (Roche, 
2005). In Quran, in the story of Saul and Goliath battle it is inferred that what kept Saul friends stable was their following the law i.e. because they accepted the rule of not drinking water, they remained in Saul`s fellowship and remained their unity and they got what they wanted (Sobhani, 1991).

\subsection{The Development of Society in Various Scenes}

Social and cultural development depends on political and economic power, it means that a society can take steps towards Development, progress and social development that equip itself Economically and politically. Otherwise, we have to wait for wheels of development to stop and regression to happen. In addition, the accelerated development of tomorrow is the result of foresight and careful planning and their subtle implementation. Without acceptable discipline, achieving this condition is impossible and impractical. Thus, only in the light of the observance of law and order it is possible to plan, implement, direct programs to achieve the lofty goals of development in various aspects of life.

\section{Conclusion}

Islam guarantees human happiness in all aspects of life and it determines aspects of life and life policies and practices of social and human right. It leads human towards spiritual and social perfection and promotes them to the highest degree of humanity. Obviously, this religion should have a coherent planning for reaching their goals. Therefore, God, as the founder of this religion, sent Quran to the man which is full of solutions and value for human happiness and a better life. Thus, Qur'an is calling for mercy and goodness for all mankind and asks human to live on the basis of belief and proper thought not based on material and worldly relations. Quran is a set of fixed noble human values and people reach peace by implementing these laws and they also cause their families and society reach peace.

In Islam and Quran, the condition for salvation of a society is Adhere to the rules and regulations of the divine law in all social aspects and arenas. So our today`s society needs to be able to have a society filled with justice and equality by following Quran and Quranic teachings and we could provide the ground for the Savior of mankind. If the laws and regulations on social relations in modern society are rooted in and inspired by Quran, they can be very helpful in spreading justice, fairness and equality among people and reducing social distortions in various areas of society. Therefore, compliance with laws and regulations, in addition to regulating people's personal and social life and enabling social reforms, one of the important objectives of the proper and humanitarian -based law is to specify the direction of human movement towards social changes. From the perspective of Quran, the fact that human is social and the necessity of social life has been proved.

\section{References}

Cohen, R. (2000). The Principles of Sociology, translator M. Salasi. Tehran, Nashre Ney publication.

Jaafari Langroodi, M. J. (2001). The terminology of Law. Tehran, Ganje Danesh Library.

Khorramshahi, B. D. (2008). The knowledge of the Quran. Tehran, Nahid publication. 
Majlesi, M. B. (1984). The Bihar al-Anwar, translated by Ali Davani. Tehran,Ganjine Marefat publication.

Mesbah, M. T. (1996). Islamic government and the Supreme. Tehran, Tablighat Eslami Institution.

Meshkini, A. (1985). Mebah Al Monir. Tehran, Bonyade BeEsat publication.

Mohammadi Reyshahri, M. (2002). Selection of Mizan Al Hekmah. Qom, Dar al-Hadith publication.

Payandah, A. (2001). The Nahj Alfasaheh. Tehran, Donyaye Danesh publication.

Roche, G. (2005). The social changes, translator M. Salasi. Tehran, Nashre Ney publication.

Shihab al-Dini, M. A. (1983). The Almsttrf, translations doctor Mahmoud khorsandi. Tehran, Asatir publication.

Sobhani, J. (1991). The foundations of the Islamic regime, translation and writing of Davood Elhami, Qom, Tohid publication.

Tabatabai, M. H. (1989). Almizan fi tafsiro alQuran, translation.

Haghpanah, R. (1988). The "place of law and the rule of law in Quran". Andisheh Hoze Magazine, (IV).

Zahedi, E. (2002). The Koran" the eternal miracle of Islam". Qom, Altayar publication.

\section{Copyright Disclaimer}

Copyright for this article is retained by the author(s), with first publication rights granted to the journal.

This is an open-access article distributed under the terms and conditions of the Creative Commons Attribution license (http://creativecommons.org/licenses/by/3.0/). 